\title{
Exploring Metacognitive Online Reading Strategies among University Students in Four Nonnative English Speaking Countries
}

\author{
Yoo-Jean Lee \\ James Chamwada Kigamwa \\ Suphawat Pookcharoen \\ Vichea In
}

\begin{abstract}
In this cross-cultural study, the researchers investigated metacognitive online reading strategies of students from four countries: Cambodia, Thailand, South Korea, and Kenya. An online self-report survey of reading strategies (OSORS) was administered to 132 university students from the four countries. The self-report survey tool was then complemented through a think-aloud procedure administered to eight randomly selected students. The students were instructed to "speak out" their thoughts as they navigated around an online text. ANOVAs were applied to examine whether there were significant differences in the students' use of strategies from the different countries. The researchers also analyzed the think-aloud outputs from each student to determine the strategies that were used. The findings show that the students from the four countries differed significantly only in their use of global online reading strategies, but not in their use of problem-solving and support strategies.
\end{abstract}

\section{Introduction}

A number of studies have examined online reading comprehension among nativeEnglish-speaking students (Coiro \& Dobler, 2007; Corio, Knobel, Lankshear \& Leu, 2008; Leu, Kinzer, Coiro \& Cammack, 2004; Leu, Zawilinski, Castek, Banerjee, Housland, Liu \& O'Neil, 2007), but few, if any, have attempted to replicate similar research among nonnative-English-speaking students. Based on a self-reported survey, Anderson (2003) documented metacognitive online reading strategies among ESL and EFL students. A major limitation of that study is that it relied on selfreported data. This study supplements self-reporting with think-aloud data, and attempts to compare the use of strategies among college students from four different countries. Using the think-aloud data to triangulate with the survey data provides new insights into metacognitive online reading strategies and the use of the self-reported survey method to document the strategies. 
This study seeks to answer the following two questions:

1. What metacognitive online reading strategies do students in different countries report using?

2. How do students in different countries use metacognitive online reading strategies?

\section{Literature Review}

An extensive body of research has established an inextricable relationship between readers' strategies and reading comprehension (e.g. Carrell, 1988; Sizoo, Malhotra \& Bearson, 2003). These studies agree that the effective use of reading strategies contributes to reading comprehension. Thus, what expert readers do has received a great deal of attention from many research studies which argue that readers' high levels of reading comprehension are of particular relevance to their cognitive effort, referred to as metacognitive processing (Bazerman, 1985; Pressley \& Afflerbach, 1995). Brown (1980) defines metacognition as "the deliberate conscious control of one's own cognitive actions" (p. 453). During reading, metacognitive strategies are employed to "oversee, regulate, and direct the language learning task, and invoke thinking about the learning process" (Vandergrift, 2002, p. 559). Research suggests that the use of metacognitive reading strategies can help readers overcome problems they encounter and ultimately achieve reading comprehension.

Sheorey and Mokhtari (2001) developed the Survey of Reading Strategies (SORS) to discover offline reading strategies used by post-secondary students. They tried to find differences in metacognitive awareness of reading strategies between ESL and college students studying in the United States and native-English-speaking American college students. They also looked at whether there were differences based on gender. However, the SORS was designed to measure not only metacognitive strategies but also other strategies such as cognitive and support strategies. Nonetheless, the authors did not explain how students' use of metacognitive, cognitive, and support strategies were similar or different.

Based on the SORS, Anderson (2003) created Online Survey of Reading Strategies (OSORS) to compare ESL and EFL students' different use of metacognitive online reading strategies. Even though the research attempted to examine the role of strategies used by second-language readers within the context of online reading tasks, it merely reported the results of the OSORS, and failed to discuss individual students' differences as well as their actual use of strategies when undertaking online reading tasks. With this information, the research would have provided a more detailed explanation of how students employed the strategies they reported using.

Relative to the new literacies perspective, Coiro and Dobler (2007) explored online cognitive processes for reading comprehension. They focused on how 11 advanced-level sixth-graders searched for and located information on the Internet through given online reading texts and comprehension questions, and what kinds of cognitive strategies they employed. They also conducted in-depth interviews with all students, and used think-aloud protocols while reading. Coiro and Dobler included 
only advanced-level students as participants and observed how the students did while reading two academic reading texts.

There is limited information on the role played by metacognitive strategies in the online reading contexts, particularly in reading among second-language speakers of English. By determining the metacognitive reading strategies of secondlanguage English speakers in other parts of the world, the present researchers hope to offer significant information for language teachers and researchers in nonnativeEnglish-speaking countries.

\section{Theoretical Framework}

The theories that guide this study are based on the notions of metacognition and learning (Anderson, 2003), those that underlie reading of multimodal texts in a new literacies framework (Gee, 1999; Street, 1984), and cognitive flexibility theory (Spiro, Fletovich, Jacobson \& Coulson, 1991).

Reading employs metacognitive tools and generally involves planning, monitoring, and evaluating (Anderson, 2002; Anderson, 2003; 0'Malley \& Chamot, 1990). Online reading comprehension processing requires functions such as developing important questions, locating, critically analyzing, synthesizing, and communicating information (Leu \& Szwilinski, 2007); all these are metacognitive strategies. Metacognition is simply defined as thinking about thinking (Anderson, 2008), and has to do with the control of cognitive processes that are used in learning (Livingston, 1997). It can also be viewed as two simultaneous things that take place as one engages in a task, thinking-in the process and thinking-of the process. Flavell (1979) defines metacognition as constituting the three components of knowledge of self, knowledge of task, and knowledge of strategies. Based on the notions of metacognition, the current study will focus on how the participants who are engaged in online reading reflect on their own cognitive processes, and how they monitor and regulate their use of cognitive processes.

In a new literacies paradigm, online reading is viewed as an engagement with multimodal texts (Pahl \& Rowsell, 2005). Online reading employs the use of multimodal media with several modes of communication, such as speech, writing, and graphic images, in an integrated way to convey meaning (Kress \& Leeuwen, 2001). Reading strategies that are different from traditional reading strategies will be required for online readers to develop questions, and to locate, evaluate, combine, and communicate information on the Internet (Leu et al., 2004). Recent research studies embracing a new literacy studies paradigm have tried to address the question of what new skills, strategies and dispositions are necessary for online learning. Castek et al. (2007) further note that the nature of literacy is constantly changing, and that more research is focusing on how the Internet and other social practices are redefining literacy.

Harnessing together the theories that guide the notions of metacognition and those that underlie reading of multimodal online texts are theories of cognitive flexibility which account for the ability to "adaptively re-assemble diverse elements 
of knowledge to fit the particular needs of a given understanding or problem-solving situation" (Spiro \& Jehng, 1990, p. 169). In order to comprehend online texts, online readers must employ purposeful as well as flexible choices of various media as they construct meaning from online texts, a process which requires flexibility in reassembling existing knowledge (Coiro \& Dobler, 2007).

\section{Methodology}

\section{Participants}

132 undergraduate students aged 19 to 40 years were recruited from universities in Cambodia, Kenya, Korea, and Thailand. The voluntary nature of participation led to a nonrandomized sampling. Students were also not limited to any particular major. After they completed answering the survey questions, a scoring guideline was provided so that they could interpret their scores. This also served to raise their awareness of online reading processes as a preparation for the think-aloud procedure. Later, two students were randomly selected from each country to participate in a think-aloud task. The researchers explained the importance and advantages of their participation in the task, provided advice and suggestions for enhancing their awareness of the use of online reading strategies, and shared the study results with them.

\section{Data Collection}

Students were given the Online Survey of Reading Strategies (OSORS) (Anderson, 2003), which is an adapted form of the Survey of Reading Strategies (SORS) (Sheorey \& Mokhtari, 2001), in order to identify online reading strategies they used. The SORS is designed to measure offline reading strategies in academic reading contexts, and has 30 items. It measures three categories of reading strategies: global, problem-solving, and support strategies. On the other hand, the OSORS, the adapted form of the SORS, is designed to measure metacognitive online reading strategies. It also contains the same three categories of reading strategies as the SORS does, but consists of 38 items instead of 30, each using a 5-point Likert scale for responses (See Appendix 1 for the three subsections of the OSORS). The point 5 means "always or almost always" and 1 means "never." The survey was administered using Survey Monkey, an online survey tool, and included all 38 items plus eight background information questions (i.e., gender, age, major, years of learning English, reasons for learning English, importance of becoming proficient in English, overall English proficiency level, hours spent reading online per day, and areas of interest in reading online). The students received an email with the link to this survey.

After analyzing students' answers, the top three strategies in each of the three categories were identified according to the four countries. Students from each country who indicated the top three strategies in each of the three categories the most (by checking "usually" or "always or almost always" for the use of those strategies in the survey) were randomly selected for a think-aloud task. Based on a number of factors, including their willingness, diversity in majors, availability of 
time, and access to the Internet, two students from each country were purposefully selected. The eight students (six males and two females) were then asked to read an article about global warming from National Geographic (http://environment.nationalgeographic.com/environment/global-warming/gwoverview.html). The article had less than 900 words and was comprised of 20 paragraphs. It is also rated at the US grade level 10.1 by the Flesch-Kincaid leveling using the MS Word text difficulty feature. Since the students had studied English as a second language for about 10 years, the researchers thought that providing a text with a US high school level (i.e., 10.1 grade level) would be appropriate for them, even though they were university students.

Furthermore, the topic of global warming was chosen because the researchers thought students from different cultural backgrounds might be quite familiar with it, since they all expressed interest in local and world news. The researchers discussed ahead of time what kinds of questions should be asked and what should be observed from the students. A specific guideline for the think-aloud procedure was created by the researchers so that there would be some standardization of questions for each student in order to subsequently enhance validity and inter-rater reliability. Before the "formal" think-aloud interviews began, the researchers explained what the students were supposed to do and modeled the exercise using a text about recycling electronics that had a similar format to the actual think-aloud text. The students were then asked to talk about how they read the given text and what kinds of strategies they used to comprehend the text.

Since the researchers and students were in different countries, the communication was facilitated via Skype; "software that allows users to make telephone calls over the Internet" ("Skype," 2012, para. 1). All researchers and students used Pamela for Skype (http://www.pamela-systems.com) to record Skype call conversations. During the think-aloud sessions, the researchers and the students used both English and their first language. Later the conversations were transcribed, and member checks were conducted in cases where there was a need to clarify specific issues in the transcripts.

\section{Data Analysis}

To answer the first research question, the researchers identified first the mean scores and standard deviations of the overall students and then divided the students by country and examined those scores and standard deviations for the 38 items. The top three strategies in general and in the three subsections (i.e., global strategies, problem-solving strategies, and support strategies) according to the four different countries were identified. Also, ANOVAs were applied to examine whether significant differences existed among the four countries on the three subsections of the OSORS. To answer the second research question, the recorded think-aloud conversations were analyzed qualitatively to determine how the students used the different online reading strategies. The most frequently used strategies in each subsection reported in each student's survey questionnaire (i.e., the strategies marked as "usually," which was point 4, and "always or almost always," which was 
point 5) and the strategies in each subsection actually used during the think-aloud task were compared. Then, the reasons why the students used or did not use the self-reported reading strategies during the think-aloud task were explained with examples. Comparing the students' reported use of strategies with their actual use would have great significance, in that it can make up for the limitations of simply using the self-reported survey data. In addition, listening to the reasons for using or not using the reported strategies in actual reading would provide explicit and indepth explanations of what is going on in the students' minds, that is, their overall reading processes.

\section{Results and Discussions}

What metacognitive online reading strategies do students in different countries report using?

The first research question in this study was directed towards identifying the metacognitive online reading strategies used by the students in the four countries. According to the students' response to the OSORS, those in the four countries used the following global strategies the most:

\#1. I have a purpose in mind when I read online.

\#6. I take an overall view of the online text to see what it is about before reading it.

\#14. When reading online, I decide what to read closely and what to ignore.

With regard to problem-solving strategies, the students used the following strategies most:

\#13. I adjust my reading speed according to what I am reading online.

\#16. When online text becomes difficult, I pay closer attention to what I am reading.

\#28. When online text becomes difficult, I reread it to increase my understanding.

The following support strategies were used the most by all the students:

\#15. I use reference materials (e.g., an online dictionary) to help me understand what I read online.

\#21. I paraphrase (restate ideas in my own words) to better understand what I read online.

\#25. I go back and forth in the online text to find relationships among ideas in it.

These findings, including the means and standard deviations, are summarized in Table 1 below. 


\begin{tabular}{|c|c|cc|}
\hline Strategy Type & Strategy Number & Mean & Std. Deviation \\
\hline Global & 1 & 3.58 & 1.15 \\
& 6 & 3.70 & 1.10 \\
\hline Problem- & 14 & 3.81 & 1.05 \\
\hline solving & 13 & 3.48 & 1.06 \\
\hline Support & 16 & 3.49 & 1.05 \\
\hline & 28 & 3.55 & 1.04 \\
\hline & 15 & 3.39 & 1.10 \\
\hline
\end{tabular}

Table 1. Top three strategies used by all students

The strategies used the most by the students from the four countries and their mean scores and standard deviations are presented in Table 2 . In the case of Cambodia, four top support strategies are identified since the mean scores for strategies number 21 and 38 were the same $(M=3.09)$. Similarly, in the case of Thailand, four top global strategies are identified since the mean scores for strategies number 14 and 20 were equal $(M=3.48)$. In the case of Kenya, support strategy numbers 12 and 21 topped the section with means of 3.97 and 3.91 respectively. Four strategies (\#4, \#15, \#25, and \#29) tied for third place, with each scoring a mean of 3.27, but the researchers did not include them in the table since it seemed to be too unwieldy to list all of them. In some cases, the strategies used the most in specific countries matched the top three strategies used by all students in general; for example, global strategies number 6 and 14 were used not only by Kenyan students but also by all the students in general. However, there were some top strategies unique to specific countries, for example, the problem-solving strategies number 11 and 31, which Korean students used, were not the ones that the all students in general used.

\begin{tabular}{|c|c|c|c|c|c|c|c|c|c|c|c|c|}
\hline $\begin{array}{l}\text { Strategy } \\
\text { Type }\end{array}$ & Cambodia & $\mathbf{M}$ & SD & Kenya & $\mathbf{M}$ & SD & Korea & $\mathbf{M}$ & SD & Thailand & $\mathbf{M}$ & SD \\
\hline \multirow[t]{4}{*}{ Global } & $\# 1$ & $\begin{array}{l}3.7 \\
3\end{array}$ & $\begin{array}{l}1.1 \\
0\end{array}$ & $\# 6$ & $\begin{array}{l}4.3 \\
9\end{array}$ & .97 & $\# 6$ & 3.42 & .90 & $\# 1$ & $\begin{array}{l}3.4 \\
8\end{array}$ & $\begin{array}{l}1 . \\
09\end{array}$ \\
\hline & $\# 14$ & $\begin{array}{l}3.7 \\
6\end{array}$ & $\begin{array}{l}1.2 \\
0\end{array}$ & \#14 & $\begin{array}{l}4.3 \\
6\end{array}$ & .99 & $\# 14$ & 3.64 & .90 & \#6 & $\begin{array}{l}3.5 \\
8\end{array}$ & $\begin{array}{l}1 . \\
09\end{array}$ \\
\hline & $\# 20$ & $\begin{array}{l}3.7 \\
0\end{array}$ & $\begin{array}{l}1.1 \\
3\end{array}$ & $\# 26$ & $\begin{array}{l}4.1 \\
5\end{array}$ & .87 & $\# 32$ & 3.36 & .82 & $\# 14$ & $\begin{array}{l}3.4 \\
8\end{array}$ & $\begin{array}{l}.9 \\
1\end{array}$ \\
\hline & & & & & & & & & & $\# 20$ & $\begin{array}{l}3.4 \\
8\end{array}$ & $\begin{array}{l}1 . \\
15\end{array}$ \\
\hline \multirow{3}{*}{$\begin{array}{l}\text { Proble } \\
\text { m- } \\
\text { solving }\end{array}$} & $\# 13$ & $\begin{array}{l}3.7 \\
3\end{array}$ & .84 & $\# 28$ & $\begin{array}{l}3.7 \\
0\end{array}$ & 1.16 & $\# 11$ & 3.42 & .83 & $\# 16$ & $\begin{array}{l}3.5 \\
2\end{array}$ & $\begin{array}{l}1 . \\
03\end{array}$ \\
\hline & $\# 16$ & $\begin{array}{l}3.8 \\
8\end{array}$ & .86 & $\# 34$ & $\begin{array}{l}3.8 \\
8\end{array}$ & 1.39 & $\# 13$ & 3.67 & .78 & $\# 22$ & $\begin{array}{l}3.5 \\
8\end{array}$ & $\begin{array}{l}.9 \\
7\end{array}$ \\
\hline & $\# 31$ & $\begin{array}{l}3.9 \\
7\end{array}$ & .98 & $\# 36$ & $\begin{array}{l}4.1 \\
5\end{array}$ & 1.15 & $\# 31$ & 3.42 & .83 & $\# 28$ & $\begin{array}{l}3.4 \\
5\end{array}$ & $\begin{array}{l}.9 \\
1\end{array}$ \\
\hline Support & $\# 15$ & 3.2 & 1.2 & $\# 12$ & 3.9 & 1.36 & $\# 15$ & 3.30 & .98 & $\# 15$ & 3.7 & .9 \\
\hline
\end{tabular}




\begin{tabular}{|c|c|c|c|c|c|c|c|c|c|c|c|}
\hline & 4 & 8 & & 7 & & & & & & 3 & 8 \\
\hline \#21 & $\begin{array}{l}3.0 \\
9\end{array}$ & $\begin{array}{l}1.0 \\
1\end{array}$ & \#21 & $\begin{array}{l}3.9 \\
1\end{array}$ & 1.18 & \#25 & 3.18 & .88 & \#21 & $\begin{array}{l}3.5 \\
5\end{array}$ & $\begin{array}{l}1 . \\
09\end{array}$ \\
\hline$\# 25$ & $\begin{array}{l}3.2 \\
7\end{array}$ & $\begin{array}{l}1.0 \\
1\end{array}$ & & & & \#38 & 3.03 & $\begin{array}{l}1.0 \\
2\end{array}$ & \#25 & $\begin{array}{l}3.3 \\
3\end{array}$ & $\begin{array}{l}.9 \\
9\end{array}$ \\
\hline \#38 & $\begin{array}{l}3.0 \\
9\end{array}$ & $\begin{array}{l}1.2 \\
6\end{array}$ & & & & & & & & & \\
\hline
\end{tabular}

Table 2. Strategies used the most by the students in each country

The mean scores and standard deviations for the three subsections of the strategies that students in general used are shown in Table 3.

\begin{tabular}{|l|l|c|c|c|c|}
\hline Strategy Type & $\mathbf{N}$ & Minimum & Maximum & Mean & Std. Deviation \\
\hline Global & 132 & 1.67 & 4.44 & 3.26 & .61 \\
\hline Problem-solving & 132 & 1.18 & 4.73 & 3.34 & .68 \\
\hline Support & 132 & 1.11 & 4.56 & 2.95 & .69 \\
\hline
\end{tabular}

Table 3. Mean Scores and Standard Deviations for the three subsections of the OSORS

The students used problem-solving strategies the most, global strategies the second most, and support strategies the least. The ANOVA results in Table 4 show that there is a significant difference among the four countries in the use of global strategies $(\mathrm{F}=4.943, \mathrm{p}<.003)$ but not in problem-solving and support strategies, indicating that the students in the four countries varied in their use of global strategies.

\begin{tabular}{|l|l|l|l|l|l|l|}
\hline $\begin{array}{l}\text { Strategy } \\
\text { Type }\end{array}$ & Analysis/Source & $\begin{array}{l}\text { Sum of } \\
\text { Squares }\end{array}$ & df & Mean Square & F & Sig. \\
\hline Global & Between Groups & 5.023 & 3 & 1.674 & 4.943 & $.003^{*}$ \\
\cline { 2 - 8 } & Within Groups & 43.356 & 128 & .339 & & \\
\cline { 2 - 8 } & Total & $\mathbf{4 8 . 3 7 8}$ & $\mathbf{1 3 1}$ & & & \\
\hline \multirow{2}{*}{$\begin{array}{l}\text { Problem- } \\
\text { solving }\end{array}$} & Between Groups & 1.360 & 3 & .453 & .987 & .401 \\
\cline { 2 - 8 } & Within Groups & 58.750 & 128 & .459 & & \\
\cline { 2 - 8 } & Total & $\mathbf{6 0 . 1 0 9}$ & $\mathbf{1 3 1}$ & & .954 & .417 \\
\hline \multirow{3}{*}{ Support } & Between Groups & 1.360 & 3 & .453 & & \\
\cline { 2 - 8 } & Within Groups & 60.801 & 128 & .475 & & \\
\hline & Total & $\mathbf{6 2 . 1 6 0}$ & $\mathbf{1 3 1}$ & & & \\
\end{tabular}

Table 4. ANOVA among the four countries for the three subsections of the OSORS * $p<.05$

However, the students' use of problem-solving strategies and support strategies did not vary much. The mean scores and standard deviations for the strategy use of the students in each country are shown in Table 5. Also, graphs of mean scores among the students in the four countries are shown in Figure 1. 


\begin{tabular}{|l|l|l|l|l|l|l|l|}
\hline $\begin{array}{l}\text { Strategy } \\
\text { Type }\end{array}$ & Country & $\mathbf{N}$ & Mean & $\begin{array}{l}\text { Std. } \\
\text { Deviation }\end{array}$ & $\begin{array}{l}\text { Std. } \\
\text { Error }\end{array}$ & Minimum & Maximum \\
\hline Global & Cambodia & 33 & 3.32 & .64 & .11 & 1.72 & 4.22 \\
\cline { 2 - 8 } & Kenya & 33 & 3.53 & .61 & .11 & 2.06 & 4.44 \\
\cline { 2 - 8 } & Korea & 33 & 2.99 & .39 & .08 & 2.06 & 4.00 \\
\cline { 2 - 8 } & Thailand & 33 & 3.21 & .65 & .11 & 1.67 & 4.39 \\
\cline { 2 - 8 } & Total & $\mathbf{1 3 2}$ & $\mathbf{3 . 2 6}$ & $\mathbf{. 6 1}$ & $\mathbf{. 0 5 3}$ & $\mathbf{1 . 6 7}$ & $\mathbf{4 . 4 4}$ \\
\hline \multirow{4}{*}{$\begin{array}{l}\text { Problem- } \\
\text { solving }\end{array}$} & Cambodia & 33 & 3.43 & .57 & .10 & 2.18 & 4.55 \\
\cline { 2 - 8 } & Kenya & 33 & 3.45 & .86 & .15 & 1.18 & 4.64 \\
\cline { 2 - 8 } & Korea & 33 & 3.21 & .53 & .09 & 1.64 & 4.36 \\
\cline { 2 - 8 } & Thailand & 33 & 3.27 & .70 & .12 & 1.91 & 4.73 \\
\cline { 2 - 8 } & Total & $\mathbf{1 3 2}$ & $\mathbf{3 . 3 4}$ & $\mathbf{. 6 8}$ & $\mathbf{. 0 6}$ & $\mathbf{1 . 1 8}$ & $\mathbf{4 . 7 3}$ \\
\hline \multirow{5}{*}{ Support } & Cambodia & 33 & 2.99 & .76 & .13 & 1.67 & 4.44 \\
\cline { 2 - 8 } & Kenya & 33 & 3.01 & .77 & .13 & 1.11 & 4.56 \\
\cline { 2 - 8 } & Korea & 33 & 2.77 & .54 & .09 & 1.56 & 3.67 \\
\cline { 2 - 8 } & Thailand & 33 & 3.01 & .67 & .12 & 1.89 & 4.44 \\
\cline { 2 - 8 } & Total & $\mathbf{1 3 2}$ & $\mathbf{2 . 9 5}$ & $\mathbf{. 6 9}$ & $\mathbf{. 0 6 0}$ & $\mathbf{1 . 1 1}$ & $\mathbf{4 . 5 6}$ \\
\hline
\end{tabular}

Table 5. Mean Scores and Standard Deviations among the four countries for the three subsections of the OSORS
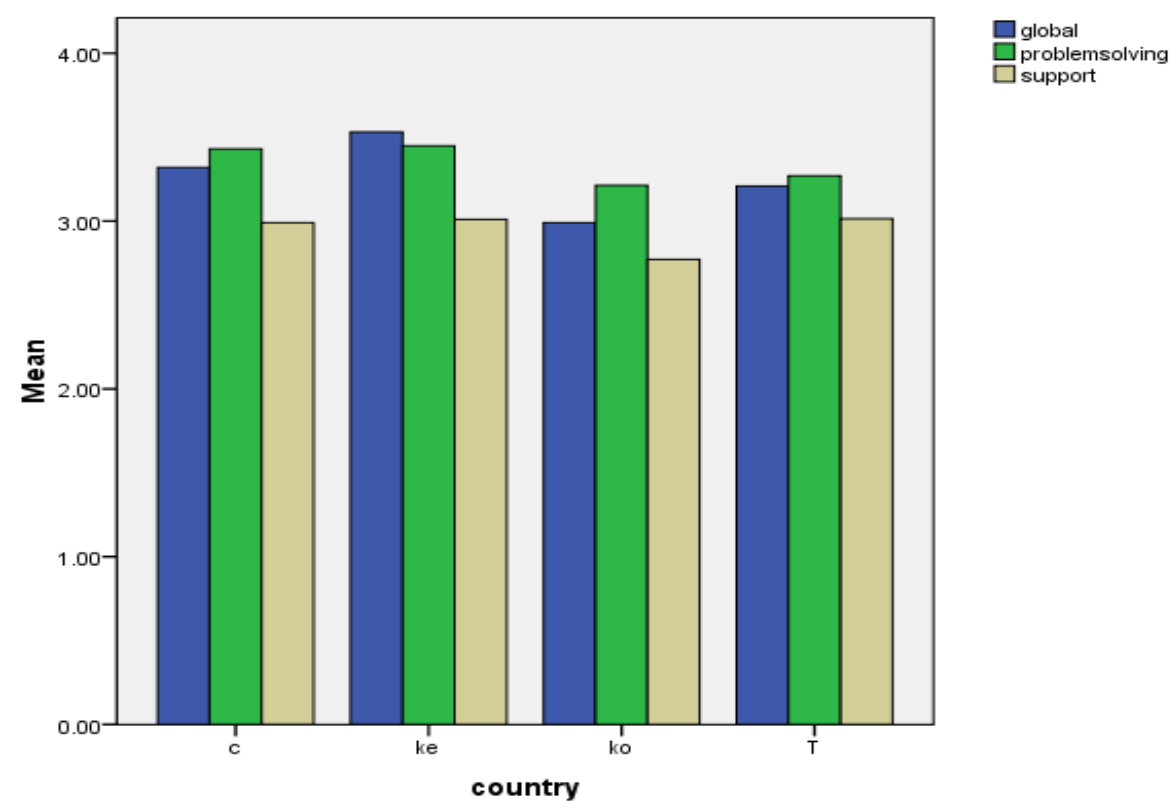

$\square$ support

Figure 1. Bar graphs of the mean scores among the four countries. *Note: C: Cambodia, Ke: Kenya, Ko: Korea, T: Thailand

Even though the mean scores of the three subsections used in each country varied, overall problem-solving strategies were used the most, global strategies the second most, and support strategies the least. However, the strategy use of Kenyan students was unique. They used global strategies the most $(\mathrm{M}=3.53, \mathrm{SD}=.61)$, problem-solving strategies the second most $(\mathrm{M}=3.45, \mathrm{SD}=.86)$, and support 
strategies the least $(\mathrm{M}=3.01, \mathrm{SD}=.77)$. No clear evidence was found in the literature, but the researchers assumed that the reason for this might be due to different English-teaching methods in Asia from in Africa. Whereas Asian students are taught to solve all comprehension difficulties immediately before moving on to the next part of a text, African counterparts are taught to monitor and manage their overall reading processes rather than dealing with comprehension difficulties. Accordingly, Cambodian, Korean, and Thai students in this study might have used problemsolving strategies more, which are applied when "[working] directly with texts" (Mokhtari \& Sheorey, 2002, p. 4) and when encountering comprehension problems (Monos, 2005). However, Kenyan students might have used global strategies more, which are "intentional, carefully planned techniques" (Mokhtari \& Sheorey, 2002, p. 4) and applied when monitoring one's own reading (Monos, 2005).

\section{How do students in different countries use metacognitive online reading strategies?}

The background information on the eight students who were selected for the thinkaloud task is shown in Table 6.

\begin{tabular}{|l|l|l|l|l|}
\hline Student & Gender & Major & Age & $\begin{array}{l}\text { Self-rated overall English } \\
\text { proficiency level }\end{array}$ \\
\hline C1 & Male & Computer Science & 19 & Fair \\
\hline C2 & Female & English \& Medicine & 19 & Good \\
\hline Ke1 & Male & Mathematics & 22 & Good \\
\hline Ke2 & Male & Medicine & 21 & Excellent \\
\hline Ko1 & Male & Law & 27 & Good \\
\hline Ko2 & Female & Business & 22 & Good \\
\hline T1 & Male & Political Science & 22 & Poor \\
\hline T2 & Male & Economics & 24 & Excellent \\
\hline
\end{tabular}

Table 6. Background of students who participated in the think-aloud task

\section{Strategies used most by students during the think-aloud task}

Among the 38 strategies in the OSORS, global strategy \#14 (When reading online, I decide what to read closely and what to ignore) was the only one that was identified by the researchers as being used frequently by all eight of the students. However, only seven of them used this strategy during the think-aloud task. Global strategy \#26 (I check my understanding when I come across new information) came second, with seven out of the eight students identified as using it frequently. Yet only five students used this strategy during the think-aloud task.

There were at least three other global strategies that were identified by the researchers (from the survey results) as being frequently used by six of the eight students: strategy \#1 (I have a purpose in mind when I read online), which was observed to be used by four of the students; strategy \#6 (I take an overall view of the online text to see what it is about before I read it), which four out of six students were observed to use; and strategy \#32 (I scan the online text to get a basic idea of 
whether it will serve my purposes before choosing to read it), which two out of six students were observed to use.

Of the ten problem-solving strategies identified by the researchers as being used frequently by the eight students, strategy \#13 (I adjust my reading speed according to what I am reading online) was observed to be used by six of the students; strategy \#28 (When an online text becomes difficult, I reread it to increase my understanding) was observed to be used by five of the students; and strategy \#22 (I try to picture or visualize information to help remember what I read online) was observed to be used by three of the students.

Nine support strategies were identified by the researchers as frequently used by the eight students. Two of them were selected by six students as being used frequently: strategy \#29 (I ask myself questions I'd like to have answered in the online text), which was observed to be used by four of the students; and strategy \#25 (I go back and forth in the online text to find relationships among ideas in it), which was observed to be used by three of the eight students.

\section{Strategies used least by students during the think-aloud task}

There were five strategies that were not observed in the think-aloud task, despite being identified by the researchers as being frequently used by the eight students in the survey. These were global strategy \#2 (I participate in live chat with other learners of English), \#3 (I participate in live chat with native speakers of English), and \#17 (I read pages on the Internet for academic purposes), problem-solving strategy \#9 (I read slowly and carefully to make sure I understand what I am reading online), and support strategy \#21 (I paraphrase [restate ideas in my own words] to better understand what I read online). The inability to observe these five strategies may be due to the fact that the selected website for the think-aloud procedure did not lend itself to chatting with native speakers or other learners on the Internet. It was also not possible to observe slow reading because the students were more likely to skim through the given text and skip less important parts as they were reading it for pleasure. Similarly, paraphrasing of ideas was not observed. Since the students read the text for fun, but not for academic purposes (e.g. taking a test and/or getting a grade), they did not think it was necessary to restate difficult parts in their own words.

Two other strategies that were identified by researchers as frequently used by the students based on the survey were observed among only two of the students: global strategy \#8 (I think about whether the content of the online text fits my reading purpose) and support strategy \#12 (I print out a hard copy of the online text then underline or circle information to help me remember it). Given the fact that the thinkaloud protocol was conducted online, the students may not have had the time or even a printer next to them and thus were not able to print out a hard copy of a web page they were reading. Regarding strategy \#8, the content and purpose were already determined by the researchers. 


\section{Two Cambodian students' actual strategy use in the think-aloud task}

Reading the online English text about global warming, C1 used approximately half of the strategies he reported to almost always and usually use in his online survey response. Four strategies that he frequently used were problem-solving strategy \#16 (paying closer attention to what he was reading when the text became difficult) and \#31(guessing meaning of unknown words/phrases), and supporting strategy \#15 (using online reference materials) and \#29 (asking himself questions and seeking answers from the text). He read the text in a linear fashion from the top to the bottom. He guessed meanings of some difficult phrases while reading, hoping that the subsequent part of the text would clarify. However, he would also ignore them if his guessing did not work. "I am not sure with this phrase 'set into motion?' but I want to read on because I think the later part will tell." In the middle of the text he decided to use Webster's online dictionary to check for the meaning of the verb "enhance." This was a tactical move since the verb was the main verb in the sentence. At one point, he critiqued the text for not giving enough information. "The text says the levels of greenhouse gases have been fairly constant for the past few thousand years. But why? The text doesn't seem to provide enough information." As he read he kept this question in mind until he got the answer in the third paragraph from where he asked. The online dictionary did not always help him. He checked the word "mercury," but was overwhelmed with so many different meanings, and no one definition seemed to perfectly match the context.

C2 employed approximately $60 \%$ of strategies reported to be frequently used in her online survey response. She started reading at the title of the text and went all the way to the bottom. However, $\mathrm{C} 2$ tended to reread many paragraphs multiple times. She questioned the accuracy of information in the text, as it was not consistent with what she had learned at school. Oftentimes, she complained about the writing style (e.g., long sentences and unnecessarily difficult words). When she hit a difficult part, she would translate it into her L1. At the beginning of the text, she just guessed or skipped difficult words and phrases. As she reached the middle of the text, she became uncomfortable with the difficult words and began to use her cell phone to check for their meanings. She expressed that the reading was getting boring for her. She wanted to jump to the last paragraph of the text and read backwards paragraph by paragraph. She also tended to read aloud the difficult parts because reading aloud slowed her down and helped her concentrate. While reading, C2 also wrote down difficult words in her notebook and would go back to them later if she wanted to learn the words. Both $\mathrm{C} 1$ and $\mathrm{C} 2$ used problem-solving strategies the most, but C2 depended more heavily on them. She employed almost all the problem-solving strategies reported to be almost always and usually used in her online survey response. C2 eventually expressed that the topic was not boring, but the complex linguistic structures of the text discouraged her from reading.

Both readers reported their reading skill as good. But $\mathrm{C} 1 \mathrm{read}$ the text much faster, while C2 reread some paragraphs up to five times. C1 did not seem to have many difficulties with the text, as he was familiar with this field and thus used fewer 
strategies. C2 was struggling with the text and spent her time employing different strategies, especially problem-solving strategies.

\section{Two Kenyan students' actual strategy use in the think-aloud task}

Ke1 used 8 strategies out of 15 he had reported, while Ke2 used 11 out of 14 . Ke1 had said that he was out to discover for himself what global warming was all about, as he had stated that the previous knowledge he had was from what he had heard from other people. He took an overall view of the site before reading the presented text, and then reported that he was trying to open the video link on global warming and wanted to watch a brief audiovisual presentation of the topic. Unfortunately, his Internet connection was not fast enough, so he could not do this. He said that he liked to start by looking at a video because it gave him a good, quick overview of the subject. He stayed with the text in a more linear fashion, going from the top of the page downwards and opening the links that were available in new windows, in line with global strategy \#26 that involves checking understanding of new information.

Some of the strategies which the student did not use, despite having reported them in the survey, included problem-solving strategy \#36; he did not look for sites that addressed different sides of the issue. Despite reporting that he used problemsolving strategy \#9, which has to do with slow and careful reading, the student seemed to do the exact opposite, as he read through the website quickly. He did not print anything, so he did not use support strategy \#12, which required that he print what he wanted to read. He did not take notes either, as he had indicated in the reported data.

Ke2 was a more critical online reader than Ke1; unlike Ke1, who approached the text with a desire to learn more about global warming, Ke2 was quick to state that he did not believe global warming was real, that it was the creation of a few individuals. He added that not too long ago he had read a scientific article which indicated that $90 \%$ of the $\mathrm{CO}_{2}$ emissions into the atmosphere were from the sea, and that humans could do very little to significantly affect the overall levels of carbon dioxide in the universe.

Ke2 read with a purpose in mind, which was in line with global strategy \#1, and was looking for information on the website which would disprove the theory of global warming. It was not clear why he did not seek other sites that would give contradictory information, in line with his reported use of strategies that involve looking at sites that cover both sides of an issue. The student used his previous knowledge as well as knowledge found on the website to evaluate the theme. He read carefully to make sure he understood what he was reading, but he did not employed paraphrasing strategies, which he employed only when reading for an academic purpose.

\section{Two Korean students' actual strategy use in the think-aloud task}

When Ko1 got the global warming text, he first checked the text length and started to read the first and last paragraph quickly. He then read from the second paragraph, but skipped several paragraphs that* he did not think important. When reached the 
very last paragraph, he reread it to find the conclusion.

Of the seven global strategies he reported in the survey, he used four. He took an overall view of the text to see what it was about before reading. Also, he decided what to read closely and what to ignore while reading. He constantly checked his understanding when encountering new information. He mentioned that bold text or large font size helped him understand the text better.

Of the four problem-solving strategies reported, Ko1 used three. He slowed down or read twice when sentences seemed to be important or unclear, but speeded up when sentences discussed what he already knew. He used context to guess the meaning of unknown words. He mentioned that he usually tried to get back on track when he lost concentration.

Of the four reported support strategies, he used only one. He thought about the content in Korean after reading each paragraph. He said translating or transferring from English to Korean helped him. He usually liked to print out a copy of an online text. However, since the given text was not difficult and he could not access a printer during the think-aloud task, he did not print out a copy. In addition, he did not use an online dictionary because he could easily guess the meaning of unfamiliar words. Moreover, he could easily find relationships among ideas in the text such as cause and effect of global warming without going back and forth in the text.

Overall, Ko1's actual use of strategies matched his reported use of strategies the most with problem-solving, the second most with global, and the least with support strategies. The reasons he did not actually use all the reported strategies was because 1) he already had some background knowledge on global warming, 2) the text was relatively easy, and 3) the purpose of reading the text was to know more about global warming but not to learn a new concept or write an academic paper.

Like Ko1, Ko2 also checked the length of the text before reading it. One big difference between Ko1 and Ko2 was that Ko2 always put her right hand on the mouse and moved the mouse cursor on the screen while reading the text; whereas, Ko1 never used the mouse and simply read the text by moving his eyes.

Of the nine global strategies Ko2 reported, she used six. She reviewed the text length and took an overall view to see what it was about. Also, she said she focused more on words written in bold, which seemed to be more important. Unlike Ko1, Ko2 checked what kinds of visuals were on the page and whether those visuals would be relevant to the text. In addition, she read the text for fun but not for academic purposes, because she was not asked to write a report on it.

Of the seven problem-solving strategies, Ko2 used five. She adjusted her reading speed and read certain words or sentences again when confused. One thing unique about Ko2 was that she tended to say what she was thinking out loud.

Of the five reported support strategies, Ko2 used two. She read aloud to enhance her understanding and went back and forth to find relationships among ideas. For example, she reread several sentences to determine sequence. She finally 
concluded that "global gas" would come first, "global effect" next, and "global warming" last. For unfamiliar words, she did not use a dictionary because she thought the text was not difficult. Like Ko1, since there was no printer, Ko2 could not print it out.

Overall, Ko2's actual use of strategies matched her reported use of strategies the most with problem-solving, the second most with global, and the least with support strategies. The reason she did not actually use all the reported strategies was because 1) the text was easy to read, and 2) she read the text for pleasure but not for writing an academic paper.

\section{Two Thai students' actual strategy use in the think-aloud task}

During the think-aloud task, T1 used 15 out of 25 strategies he reported using on the survey. Although the topic was not of particular interest to him, he already had prior knowledge about the causes and effects of global warming through his initial exposure at school. According to him, this familiarity with the topic greatly facilitated his reading comprehension, particularly when he encountered certain problems related to the complicated concepts presented in the text. Some of the strategies he often used included global strategy \#23 (using bold face and italics to identify key information), and supporting strategies \#15 (using reference materials), \#25 (going back and forth in the text to find relationships among ideas), and \#37 (translation of the text from English into Thai). Reporting that his English proficiency is poor, he experienced difficulty with technical terms and other difficult words found in the text. In an attempt to decode word meanings, he consulted an English-Thai online dictionary, which was found to be overwhelming and demotivating since the text was full of unfamiliar words. "The ideas in the text are not that difficult, but I saw a lot of unknown words ... that made me want to skip reading." Surprisingly, he expressed that pictures on the page did not help foster his understanding much, since most of the times the ideas that the page presented were much more complicated than what pictures can convey. Faced with a dilemma, he purposefully selected a few topics that resonated with his interests to learn more about global warming in conjunction with his prior knowledge. Furthermore, another strategy he used to acquire a better understanding of the topic was to read an online text in Thai about global warming when the English text did not make sense to him. Even though he reported that he sometimes printed out a hard copy of the online text, he chose not to do so during this think-aloud task, as he realized that it was not intended for an academic purpose. His choice of strategy use was determined largely by the purpose of reading as well as the complexity of the reading text.

Unlike the case of T1, the English proficiency of T2 was found to be relatively excellent. He also reported a clear understanding of the topic previously learned from class. When undertaking the think-aloud task, most of the strategies he reported using frequently on the survey response were employed. Also, one marked difference between these two participants' use of strategy is that T2 appeared to feel much more familiar with a wide range of metacognitive strategies that he 
selected to utilize while reading online. As a strategy, he realized the time constraint of the reading task, which obliged him to decide what to read closely and what to ignore. In so doing, he used typographical features such as bold face to identify key information that was deemed necessary. To learn more about the topic, he asked himself questions he liked to have answered in the online text. For instance, the questions regarding the current situation of global warming were established beforehand. The questions provided him with a clear intention when navigating the webpage. Similar to T1's comment, T2 also pointed out at the end of the think-aloud session that the purpose he had in mind when he read online would not only determine what strategies he would use, but also the frequency of strategy use during any reading task. While reading for pleasure typically requires basic strategies, reading for academic purposes, for instance, calls for more sophisticated types of strategies which inevitably force readers to put more time and effort into the task.

\section{Summary of the eight students' actual strategy use in the think-aloud task}

Through the think-aloud procedures, it was found that approximately $61 \%$ of the strategies reported by the eight students in the survey questionnaire were actually used by them, as shown in Table 7.

\begin{tabular}{|c|c|c|c|c|}
\hline Student & Global & Problem-Solving & Support & Overall \\
\hline C1 & $3 / 10$ (=30\%) & $5 / 7(=71 \%)$ & $2 / 4(=50 \%)$ & $10 / 21(=48 \%)$ \\
\hline C2 & $3 / 9(=33 \%)$ & $6 / 7(=86 \%)$ & $5 / 8(=63 \%)$ & $14 / 24(=58 \%)$ \\
\hline Overall & $6 / 19(=32 \%)$ & $11 / 14(=79 \%)$ & $7 / 12(57 \%)$ & $24 / 45(=53 \%)$ \\
\hline Ke1 & $5 / 7(=71 \%)$ & $2 / 4(=50 \%)$ & $1 / 4(=25 \%)$ & $8 / 15(=53 \%)$ \\
\hline Ke2 & $7 / 7(=100 \%)$ & $2 / 4(=50 \%)$ & $2 / 3(=67 \%)$ & $11 / 14(=79 \%)$ \\
\hline Overall & $12 / 14(=86 \%)$ & $4 / 8(=50 \%)$ & $3 / 7(=46 \%)$ & $19 / 29(=66 \%)$ \\
\hline Ко1 & $4 / 7(=57 \%)$ & $3 / 4(=75 \%)$ & $1 / 4(=25 \%)$ & $8 / 15(=53 \%)$ \\
\hline Ko2 & $6 / 9(=67 \%)$ & $5 / 7(=71 \%)$ & $2 / 5(=40 \%)$ & $13 / 21(=62 \%)$ \\
\hline Overall & $10 / 16(=62 \%)$ & $8 / 11(=73 \%)$ & $3 / 9(=33 \%)$ & $21 / 36(=58 \%)$ \\
\hline T1 & $7 / 11(=64 \%)$ & $5 / 8(=63 \%)$ & $3 / 6(=50 \%)$ & $15 / 25(=60 \%)$ \\
\hline T2 & $7 / 9(=78 \%)$ & $3 / 4(=75 \%)$ & $3 / 4(=75 \%)$ & $13 / 17(=76 \%)$ \\
\hline Overall & $14 / 20(=71 \%)$ & $8 / 12(=69 \%)$ & $6 / 10(=63 \%)$ & $28 / 42(=67 \%)$ \\
\hline Total & $42 / 69(=61 \%)$ & $31 / 45$ (=69\%) & $19 / 38(=50 \%)$ & $92 / 152(=61 \%)$ \\
\hline
\end{tabular}

Table 7. Percentages of actual strategies used by students in the think-aloud

The think-aloud results of Kenya and Korea matched with the survey results. However, the think-aloud results of Cambodia and Thailand revealed a slight difference from the survey results. More specifically, Cambodian students reported that they used problem-solving strategies the most, global strategies the second most, and support strategies the least in the survey, while support strategies were observed to be use more than global strategies in the think-aloud task. Also, students in general in Thailand reported that they used problem-solving strategies the most, global strategies the second most, and support strategies the least, whereas the two Thai students used global strategies the most, problem-solving strategies the second most, and support strategies the least in the think-aloud task. 
It is important to note, however, that the difference between the average percentages of actual use of global strategies and problem-solving strategies during the think-aloud task for the two Thai students was very small $(71 \%$ and $69 \%$ respectively), and almost unreliable. For Kenya, the think-aloud results matched with the survey results, and they revealed that global strategies were used the most, problem-solving strategies the second most, and support strategies the least. For Korea, the think-aloud results also matched with the survey results, and revealed that problem-solving strategies were used the most, global strategies the second most, and support strategies the least.

Based on the survey results, Cambodian, Korean and Thai students used problem-solving strategies the most. This was confirmed by the think-aloud results of Cambodian and Korean students, but not for Thai students. Also, both the survey and think-aloud results confirmed that the most frequently used strategy by the Kenyan students was global strategies.

The least frequently used strategies based on the survey were support strategies. This result was confirmed by the think-aloud results of Kenya, Korea, and Thailand. However, for Cambodia the least frequently used strategies in the thinkaloud task were global strategies. The data collected from this study may not be adequate to explain why the think-aloud results of Cambodia differed with the survey results regarding the support strategies being the least used.

In conclusion, there were many similarities among the eight students in their actual use of strategies in the think-aloud tasks and their self-reported use of strategies in the survey. However, no major discrepancies were found between the students' actual use and reported use of strategies.

\section{Limitations}

The data from the online survey were self-reported by the participants. The problem with self-reported data is that the participants may not report what they actually do in reading, and the reported strategies are seen as constant and noncontingent. In actual reading, the participants may not use all the strategies they report in all cases of reading. What they choose to use depends on what they read and the context of the reading. The data from the online survey thus should be cautiously interpreted.

Moreover, certain strategies such as printing out the online text are not doable in the think-aloud session. Since the think-aloud session was carried out online, not onsite, and the researcher did not have the visual of what the participant did, some strategies were not possible to be observed.

The data from the think-aloud session were meant to be triangulated with the data from the online survey. However, the think-aloud data were limited to certain strategies from among the 38 strategies in the online survey; therefore, the think-aloud data do not coincide with all parts of the survey data. Due to the relatively small number of participants for the think-aloud session, the triangulation and generalizability values of the data were limited. 


\section{Implications}

The findings in this study have implications for teaching and research. Some students articulated that they were not aware of some strategies that would enhance their reading comprehension. Therefore, through explicit instruction, teachers should encourage students to utilize more metacognitive strategies while reading online, including using prior knowledge, guessing word meaning from context, skimming for main ideas, scanning for information, summarizing, and selfquestioning and prediction. To raise students' awareness of metacognitive online reading strategies, teachers should focus not only on the number of strategies students can use but also the amount of time the strategies are used.

Since it was revealed in the findings that students, regardless of their language proficiency, used their background knowledge frequently when reading online, teachers should also pay special attention to selecting texts that address students' interests and their English proficiency. Teachers can gradually proceed from easy texts to more challenging ones whose topics are of interests to students, and incorporate a student-centered approach and collaborative learning approach into instruction. In the same vein, teachers should begin with some metacognitive reading strategies that are easy for students to implement, in order to inspire their confidence and build a greater sense of achievement.

Furthermore, the findings demonstrated that the students adjusted their strategies to the type of text as well as to the purpose of their reading. For instance, they used contextual clues to decipher the meaning of unfamiliar words, and identified key information by means of such typographical features as boldface and italics. Thus, teaching students a repertoire of metacognitive reading strategies would facilitate their adjustment to the different types of texts they are reading.

Finally, the study findings suggest some important areas for further research. In an attempt to extend the scope of the current study, researchers might seek to examine whether there are any similarities and discrepancies between the participants' use of strategies in the online and offline reading environments. Moreover, it would be interesting to explore the manner in which readers use strategies when they read for different purposes, such as academic and nonacademic purposes. These empirical data would yield a better understanding of how the same readers implement metacognitive reading strategies in two contexts, in terms of their choices and frequency of strategy use. 


\section{References}

Anderson, N. J. (2002). The role of metacognition in second/foreign language teaching and learning. ERIC Digest. Washington, DC: ERIC Clearinghouse on Languages and Linguistics. Retrieved August 18, 2012, from http://www.eric.ed.gov/ERICWebPortal/search/detailmini.jsp? nfpb=true\& \&ERICExtSearch SearchValue 0=ED463659\&ERICExtSearch SearchType 0 =no\&accno=ED463659

Anderson, N. J. (2003). Scrolling, clicking, and reading English: Online reading strategies in a second/foreign language. The Reading Matrix, 3(3), 1-33.

Anderson, N. J. (2008). Metacognition and good language learners. In C. Griffiths (Ed.), Lessons from Good Language Learners (pp. 99-109). Cambridge, UK: Cambridge University Press.

Bazerman, C. (1985). Physicist reading physics: Schema-laden purposes and purposeladen schema. Written Communication, 2(1), 3-23.

Brown, A. L. (1980). Metacognitive development and reading. In R. J. Spiro, B. Bruce \& W.F. Brewer (Eds.), Theoretical issues in reading comprehension (pp. 453-479). Hillsdale, NJ: Lawrence Erlbaum.

Carrell, P. L. (1988). Interactive text processing: Implications for ESL/second language reading classroom. In P. L. Carrell, J. Devine, \& D. E. Eskey (Eds.), Interactive approaches to second language reading (pp. 239-259). New York: Cambridge University Press.

Castek, J., Leu, D. J., Jr., Coiro, J., Gort, M., Henry, L. A., \& Lima, C. (2007). Developing new literacies among multilingual learners in the elementary grades. In L. Parker (Ed.), Technology-mediated learning environments for young English learners: Connections in and out of school (pp. 111-153). Mahwah, NJ: Lawrence Erlbaum.

Coiro, J., \& Dobler, E. (2007). Exploring the online reading comprehension strategies used by sixth-grade skilled readers to search for and locate information on the Internet. Reading Research Quarterly, 42(2), 214-257.

Coiro, J., Knoble, M., Lankshear, C., \& Leu, D. J., Jr. (2008). Handbook of research on new literacies. Mahwah, NJ: Lawrence Erlbaum.

Flavell, J. H. (1979). Metacognition and cognitive monitoring: A new area of cognitive-developmental inquiry. American Psychologist, 34, 906-911.

Gee, J. (1999). An introduction to discourse analysis: Theory and method. New York: Routledge.

Kress, G., \& Van Leeuwen, T. (2001). Multimodal discourses: The modes and media of contemporary communication. London: Arnold.

Leu, D. J., \& Zawilinski, L. (2007). The new literacies of online reading comprehension. New England Reading Association Journal, 43, 1. 
Leu, D. J., Jr., Kinzer, C. K., Coiro, J., \& Cammack, D. (2004). Toward a theory of new literacies emerging from the Internet and other information and communication technologies. [Article reprinted from R. B. Ruddell \& N. Unrau (Eds.), Theoretical Models and Processes of Reading, 5th ed. (pp. 15681611). Newark, DE: International Reading Association] [Online Serial]. Available: http://www.readingonline.org/newliteracies/lit_index.asp?HREF $=/$ newliteracies $/$ leu

Leu, D. J., Zawilinski, L., Castek, J., Banerjee, M., Housand, B., Liu, Y., \& O'Neil. M. (2007). What is new about the new literacies of online reading comprehension? In A. Berger, L. Rush, \& J. Eakle (Eds.), Secondary school reading and writing: What research reveals for classroom practices (pp. 3768). Chicago: National Council of Teachers of English.

Livingston, J. (1997). Metacognition: An overview. Buffalo: State University of New York.

Mokhtari, K., \& Sheorey, R. (2002). Measuring ESL students' awareness of reading strategies. Journal of Developmental Education, 25(3), 2-10.

Monos, K. (2005). A study of the English reading strategies of Hungarian university students with implications for reading instruction in an academic context. Malaysian Journal of ELT Research. Retrieved September 10, 2012, from http://www.melta.org.my/Doc/MonosK Eng reading strategies.pdf.

O'Malley, J. M., \& Chamot, A. U. (1990). Learning Strategies in Second Language Acquisition. Cambridge: Cambridge University Press.

Pahl, K., \& Rowsell, J. (2005). Literacy and education: The New Literacy Studies in the classroom. London: Paul Chapman.

Pressley, M., \& Afflerbach, P. (1995). Verbal protocols of reading: The nature of constructively responsive reading. Hillsdale, NJ: Lawrence Erlbaum.

Sheorey, R., \& Mokhtari, K. (2001). Differences in the metacognitive awareness of reading strategies among native and non-native readers. System, 29, 431-449.

Sizoo, S., Malhotra, N., \& Bearson, J. (2003). A gender-based comparison of the learning strategies of adult business students. College Student Journal, 37, 103-110.

"Skype." In Wikipedia, the free encyclopedia. Retrieved April 19, 2012, from http://en.wikipedia.org/wiki/Skype.

Spiro, R. J., Feltovich, P. J., Jacobsen, M. J., \& Coulson, R. L. (1991). Cognitive flexibility, constructivism, and hypertext: Random Access instruction for advanced knowledge acquisition in ill-structured domains. Educational Technology, 31(5), 24-33. 
Spiro, R., \& Jehng, J. (1990). Cognitive flexibility and hypertext: Theory and technology for the nonlinear and multidimensional traversal of complex subject matter. In D. Nix \& R. Spiro (Eds.), Cognition, education and multimedia: Exploring ideas in high technology (pp. 163-205). Hillsdale, NJ: Lawrence Erlbaum.

Street, B. V. (1984). Literacy in theory and practice. Cambridge, UK: Cambridge University Press.

Vandergrift, L. (2002). It was nice to see that our predictions were right: Developing metacognition in L2 listening comprehension. The Canadian Modern Language Review, 58, 555-575.

\section{Appendix 1 Three Subsections of the OSORS}

\section{Global Reading Strategies}

1. I have a purpose in mind when I read online.

2. I participate in live chat with other learners of English.

3. I participate in live chat with native speakers of English.

5. I think about what I know to help me understand what I read on-line.

6. I take an overall view of the on-line text to see what it is about before reading it.

8. I think about whether the content of the online text fits my reading purposes before choosing to read it.

10. I review the online text first by noting its characteristics like length and organization.

14. When reading online, I decide what to read closely and what to ignore.

17. I read pages on the Internet for academic purposes.

18. I use tables, figures, and pictures in the online text to increase my understanding.

20. I use contextual clues to help me better understand what I am reading online.

23. I use typographical features like boldface and italics to identify key information.

24. I critically analyze and evaluate the information presented in the online text.

26. I check my understanding when I come across new information.

27. I try to guess what the content of the online text is about when I read.

30 . I check to see if my guesses about the online text are right or wrong.

32. I scan the online text to get a basic idea of whether it will serve my purposes before choosing to read it.

33. I read pages on the Internet for fun.

\section{Problem-solving Strategies}

9. I read slowly and carefully to make sure I understand what I am reading online.

11. I try to get back on track when I lose concentration.

13. I adjust my reading speed according to what I am reading online.

16. When an online text becomes difficult, I pay closer attention to what I am reading.

19. I stop from time to time and think about what I am reading online.

22. I try to picture or visualize information to help remember what I read online.

28. When an online text becomes difficult, I reread it to increase my understanding.

31. When I read online, I guess the meaning of unknown words or phrases.

34. I critically evaluate the online text before choosing to use information I read online.

35. I can distinguish between fact and opinion in online texts.

36 . When reading online, I look for sites that cover both sides of an issue. 


\section{Support Reading Strategies}

4. I take notes while reading online to help me understand what I read.

7. When online text becomes difficult, I read aloud to help me understand what I read.

12. I print out a hard copy of the online text then underline or circle information to help me remember it.

15. I use reference materials (e.g., an online dictionary) to help me understand what I read online.

21. I paraphrase (restate ideas in my own words) to better understand what I read online.

25. I go back and forth in the online text to find relationships among ideas in it.

29. I ask myself questions I like to have answered in the online text.

37. When reading online, I translate from English into my native language.

38. When reading online, I think about information in both English and my mother tongue. 